\title{
Influence of Renewable "Green" Energy on the Economic Development of the EU States
}

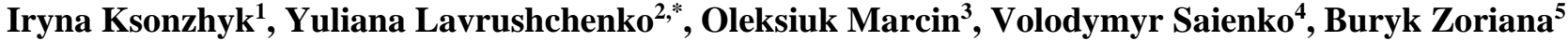 \\ ${ }^{1}$ Department of Accounting and Taxation, Faculty of Accounting and Finance, Mykolaiv National Agrarian University, Ukraine \\ ${ }^{2}$ Department of Management and Economics, National University Odessa Maritime Academy, Ukraine \\ ${ }^{3}$ Department of Entrepreneurship and Regional Policy, Faculty of Economics and Regional Policy, Academy of Management and \\ Administration in Opole, Poland \\ ${ }^{4}$ Department of Innovation Management, Faculty of Economics and Pedagogical, Academy of Management and Administration in \\ Opole, Poland \\ ${ }^{5}$ Department of Management and Business Administration, Institute of Graduate Studies and Preuniversity Education, Vasyl Stafanyk \\ Precarpathian National University, Ukraine
}

Received September 7, 2021; Revised October 4, 2021; Accepted November 7, 2021

\section{Cite This Paper in the following Citation Styles}

(a): [1] Iryna Ksonzhyk, Yuliana Lavrushchenko, Oleksiuk Marcin, Volodymyr Saienko, Buryk Zoriana, "Influence of Renewable 'Green' Energy on the Economic Development of the EU States," Environment and Ecology Research, Vol. 9, No. 5, pp. 271 - 281 , 2021. DOI: 10.13189/eer.2021.090507.

(b): Iryna Ksonzhyk, Yuliana Lavrushchenko, Oleksiuk Marcin, Volodymyr Saienko, Buryk Zoriana (2021). Influence of Renewable "Green" Energy on the Economic Development of the EU States. Environment and Ecology Research, 9(5), 271 - 281. DOI: 10.13189/eer.2021.090507.

Copyright $\odot 2021$ by authors, all rights reserved. Authors agree that this article remains permanently open access under the terms of the Creative Commons Attribution License 4.0 International License

\begin{abstract}
This article reveals the economic importance of solar energy development in the European Union in recent years. It defines the structure of energy consumption in EU countries. This structure allows us to determine how much income energy companies receive from solar electricity consumption by the population and industry. The article determines that solar energy is essential for the countries. Therefore, like any other sectors of the national economy, it forms the gross domestic product. In addition, energy companies pay taxes to the budget, which shows the economic importance of solar energy development, comparing state investments with tax revenues. The research aims to show the financial importance of solar energy for the state, i.e., how much income the state will receive in the budget by supporting solar energy development. To achieve the goal, methods of economic analysis and economic-mathematical modeling were used. They allowed confirming the hypothesis about the feasibility of investing in solar energy in European countries. The research is based on the statistical materials of 2014-2019 on the generation of solar energy, investments in it, and state budget revenues from the taxation of produced solar power. This study proves for the first time that an increase in solar energy production is beneficial to the state, despite the low level of return on
\end{abstract}

investment in the construction of solar power plants by the state. Based on economic and mathematical modeling results, a linear dependence was built, which allows forecasting the volume of tax revenues from the construction of solar power plants and electricity prices. Thus, the hypothesis about the economic feasibility of investing in solar power is confirmed.

Keywords Solar Energy, Investments in Solar Energy, State Support for Solar Energy, Taxation of Solar Energy Production

\section{Introduction}

Modern society lives in a difficult time of limited resources, which are gradually decreasing every year. This leads to the prerequisites for the development of solar energy, which is one of the key areas of transition from the consumption of carbon fuels to renewable energy sources and the use of zero greenhouse gas emission technologies [10]. The environmental aspect of solar energy development is the most important. Developed countries around the world that plan to reduce $\mathrm{CO}_{2}$ viscosities have 
developed the concept of a gradual transition to renewable energy resources [11]. However, this development is hindered by one factor - financial. Generating solar electricity is currently one of the most expensive ways to generate energy [21]. That is why the financial aspect in the field of solar energy is quite often ignored by scientific researchers because the main goal of solar energy development is environmental and political. Solar energy makes it possible to obtain resources even in those countries that do not have natural deposits of oil and gas and have to buy energy from other countries, sacrificing their economic and political independence. To a greater extent, such countries are countries of the European Union, which have a constant shortage of their own energy resources and are forced to compensate for them with imports from other countries, in particular Russia.

At the end of 2019, the European Union launched the Green Deal program [8], which provides until 2050 through green energy to become fully energy independent. This requires significant investments not only from the private sector but also from the government. Today, investment in solar energy is long-term, with about 40-60 billion EUR annually invested in the development of renewable energy in the EU [22]. EU states stimulate the development of such investments by favorable lending, improved conditions for business development, the availability of incentives, and other financial measures. Under such conditions, the average payback period for solar energy investments in EU countries is about 18 years, which makes such investments unprofitable for many private investors.

Thus, the purpose of this study is to determine the relationship between the amount of investment in solar energy development by EU countries and future government revenues.

It is possible to form a hypothesis that today for the EU countries, it is reasonable to invest in the development of solar energy to preserve renewable resources and from an economic point of view.

The scientific novelty of the study lies in the development of an economic-mathematical model of the dependence between state revenues on the volume of solar electricity production and electricity prices. This model allows us to forecast with a high probability the future volume of budget revenues from investment in solar electricity in the following years.

\section{Materials and Methods}

The study is conducted using general scientific methods, including analysis, synthesis, induction, and deduction. In particular, statistical data for 2014-2019rr on solar energy production, investments in it, and the receipt of budget revenues from the taxation of electricity use are analyzed. The information is synthesized, systematized, and presented by graphical methods.

The study also uses structural-functional, systemic, comparative, index, factor, economic-statistical, and correlation and regression analysis methods. The reciprocal relationships between the volume of solar power generation and the state revenues received from this activity are investigated using the structural-functional method. Methods of the system and comparative analysis are used to study the investment, state support, and use of solar energy in different countries of the European Union. Index and factor analysis are used to determine the influence of various factors on the financial benefits of EU states from investing in the development of solar energy. Using the methods of induction and deduction, certain regularities, common and distinctive features in the dynamics and structure of the indicators were found, which allowed forming a hypothesis about the economic benefit of solar energy generation for EU countries.

The financial importance of solar energy development is substantiated by using a correlation and regression analysis of the dependence of the received state revenues on the volume of solar energy generation. By calculating the Pearson coefficient, we obtained a high dependence index of 0.99 , which allows us to build a linear equation of the dependence of the volume of state revenues on the volume of solar energy production and the cost of light. As a result, we can build a model of the relationship between these indicators, which can be used to plan the volume of budget revenues in future periods.

The study used statistical materials from open sources and government programs for the development of renewable energy sources. All of these researched sources allow us to confirm the hypothesis that with increased incentives for the development of solar energy, the state will receive environmental, social, and economic benefits in the form of additional taxes paid to the state budget.

\section{Literature Review}

The impact of renewable energy on economic development has been widely studied in the scientific literature. In particular, the fundamental studies are Sebri \& Ben-Salha [25] and Ocal \& Aslan [16], Pirlogea \& Cicea [20], Zhe et al. [31] which were based on confirming the hypothesis that renewable energy has a direct and influence on reducing $\mathrm{CO}_{2}$ emissions and GDP growth of countries. Such studies have been conducted in the context of China, Turkey, Brazil, Russia, India. Methods of economic and mathematical modeling were used to confirm the hypotheses. New studies relevant as of 2021 include Sahlian et al. [23], which gives a positive answer to the question of increasing the production of renewable energy contributes to GDP growth in the EU.

The financial importance of solar energy development today is practically not explored in the scientific literature. Still, the scientific interest in the development of solar energy, in general, is significant. In particular, SanzCasado, Lascurain-Sáncheza, and others [24] investigated 
the scientific interest in this industry. The authors note that Germany and Spain have the largest photovoltaic capacity today; in these countries, the capacity has increased significantly in recent years. According to studies of scientific papers on the development and state of solar energy in the EU countries, scientists' interest in this topic, with the very scientific rationale for investing in solar energy, is more common than the rationale for the development of other renewable energy sources.

Perpiña Castillo C., Batista e Silva F., Lavalle C. [17] made a special contribution to the solar energy generation efficiency theory in EU countries. The authors developed a geographical map of the feasibility of building solar power plants in different countries of the European Union, based on the activity of the sun. Such studies make it possible to assess the economic feasibility of solar energy development in different countries in order to make investments in solar energy development as profitable as possible. Many authors emphasize the great importance of solar energy for households [14] and to create thermal energy. The synergistic and network effects of the economic activities of individual enterprises on the national economy are proved in their studies by Dykan [3] and Lazorko [13]. However, concerning the state benefits of investments in developing the EU solar power industry, there have been virtually no such scientific studies.

At the same time, the issue of subsidies for the installation of solar panels in Australia and the use of feedin tariffs was studied by Best, Chareunsy, Li [1]. These authors proved that the amount of investment in renewable energy depends on government subsidies. However, this found that subsidies are not always objective to different types of households. Given that all states are reducing the level of subsidies for installing solar panels, entrepreneurs and households will need to work in the new environment, taking more risks [18]. In China, the issue of solar energy is so widespread that the government hardly subsidizes investments in it. Therefore, investors must fully assess all financial risks, understanding that the price of electricity will decrease with the growth of solar power plants [30]. While in Europe, particularly in Italy, a tax deduction of $110 \%$ is planned for five years to implement solar power plants for home use [2]. A kind of subsidy for solar energy production makes it possible to abandon centralized energy supply systems.

Almost all of the studies studied are based on renewable energy, which includes solar and wind energy. The uniqueness of this study is to show the financial and especially fiscal importance of solar energy production in the EU, as other researchers have already confirmed the economic impact. As a result of the study, economists and financiers will get a formula for planning state budget revenues based on the amount of solar energy produced and its price.

\section{Research Results}

Today, the global solar energy market is worth more than $\$ 60$ billion [26]. The global market for solar energy today is 60 billion USD [26]. In the global GDP, which is estimated at 80 trillion USD, this figure is paltry. However, between 2020 and 2050, the average difference in GDP between the growth scenarios with and without solar power development is $2 \%$ on average for all countries, and in the European Union, the GDP growth rate will differ by $5 \%$. To understand the importance of solar power production in shaping GDP, we need to calculate the cost of selling the electricity produced. According to studies [15], it is found that states implement 2 price levels: for households and other consumers, which include industry, services, agriculture, transport, and the like. Typically, in the EU-28, households pay more than industry. According to statistics in 2019, households consume up to one-third of electricity, which is reflected in Figure 1.

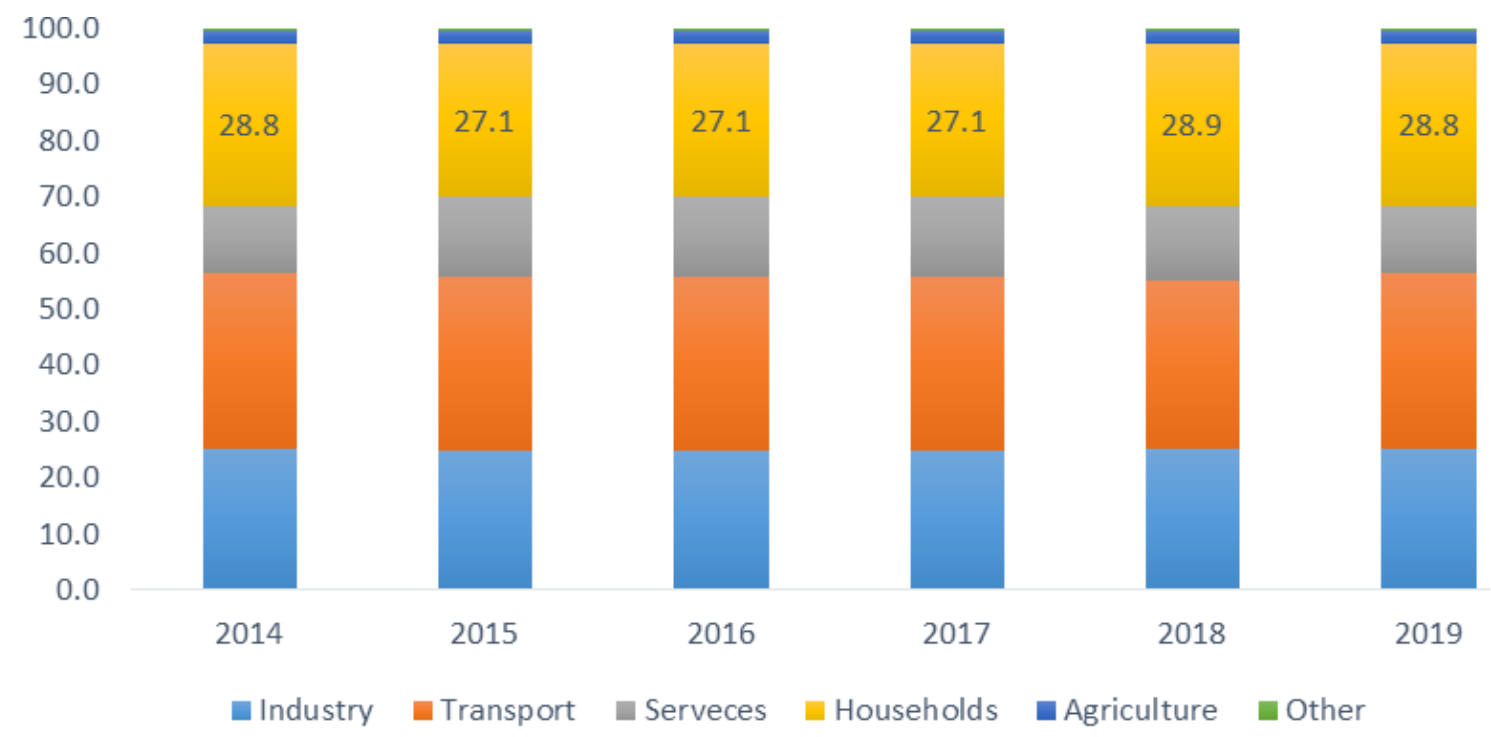

Figure 1. Structure of energy consumption in the EU-28 countries in 2020 [7] 
Table 1. Cost of solar electricity consumed by EU-28 countries in 2014-2019

\begin{tabular}{|c|c|c|c|c|c|c|c|}
\hline № & Country & 2014 & 2015 & 2016 & 2017 & 2018 & 2019 \\
\hline 1 & Austria & 104,9 & 122,5 & 140,6 & 156,7 & 183,0 & 224,6 \\
\hline 2 & Belgium & 433,3 & 440,1 & 546,1 & 602,5 & 678,5 & 741,3 \\
\hline 3 & Bulgaria & 79,6 & 84,1 & 85,7 & 86,5 & 89,0 & 97,8 \\
\hline 4 & Croatia & 3,5 & 4,6 & 5,0 & 5,2 & 6,2 & 7,7 \\
\hline 5 & Cyprus & 13,1 & 10,9 & 11,4 & 16,0 & 17,5 & 23,1 \\
\hline 6 & Czech Republic & 203,3 & 196,6 & 189,9 & 187,8 & 1143,5 & 220,6 \\
\hline 7 & Denmark & 94,3 & 117,0 & 129,3 & 130,7 & 148,0 & 147,2 \\
\hline 8 & Estonia & 0,0 & 0,4 & 0,0 & 0,0 & 0,0 & 11,2 \\
\hline 9 & Finland & 1,1 & 1,4 & 3,2 & 5,6 & 11,9 & 21,6 \\
\hline 10 & France & 637,5 & 754,3 & 802,7 & 903,9 & 1139,1 & 1312,6 \\
\hline 11 & Germany & 7454,1 & 7499,0 & 7704,6 & 8180,8 & 8734,1 & 9793,0 \\
\hline 12 & Greece & 373,4 & 344,2 & 332,8 & 346,9 & 323,9 & 342,0 \\
\hline 13 & Hungary & 7,7 & 13,0 & 25,4 & 30,0 & 69,5 & 129,4 \\
\hline 14 & Ireland & 0,2 & 0,3 & 0,9 & 1,4 & 4,8 & 6,0 \\
\hline 15 & Italy & 3618,9 & 3463,8 & 3411,2 & 3217,9 & 3235,4 & 3829,3 \\
\hline 16 & Latvia & 0,2 & 0,2 & 0,2 & 0,2 & 0,1 & 0,4 \\
\hline 17 & Lithuania & 8,3 & 7,8 & 7,8 & 7,4 & 6,8 & 8,5 \\
\hline 18 & Luxembourg & 21,1 & 14,1 & 13,2 & 13,0 & 14,4 & 16,3 \\
\hline 19 & Malta & 9,1 & 9,8 & 12,8 & 14,8 & 17,4 & 20,1 \\
\hline 20 & Netherlands & 122,0 & 161,7 & 210,2 & 284,6 & 475,8 & 876,1 \\
\hline 21 & Poland & 3,0 & 8,9 & 18,5 & 27,6 & 50,2 & 145,0 \\
\hline 22 & Portugal & 62,3 & 67,0 & 74,6 & 82,8 & 97,1 & 131,2 \\
\hline 23 & Romania & 122,6 & 124,1 & 124,0 & 123,3 & 134,4 & 150,1 \\
\hline 24 & Slovakia & 74,8 & 72,4 & 52,4 & 50,7 & 68,1 & 64,7 \\
\hline 25 & Slovenia & 27,5 & 27,4 & 24,3 & 26,0 & 27,6 & 25,6 \\
\hline 26 & Spain & 709,6 & 692,0 & 667,5 & 649,5 & 698,1 & 1393,7 \\
\hline 27 & Sweden & 8,2 & 12,1 & 15,2 & 23,0 & 45,1 & 79,7 \\
\hline \multirow[t]{4}{*}{28} & United Kingdom & 810,5 & 1501,8 & 1737,7 & 1769,7 & 1952,8 & 2304,7 \\
\hline & Total, bln & 0,0150 & 0,0158 & 0,0163 & 0,0169 & 0,0194 & 0,0221 \\
\hline & GDP, bln & 15633 & 13547 & 13883 & 14736 & 15932 & 15593 \\
\hline & $\begin{array}{c}\% \text { Solar Energy in } \\
\text { GDP }\end{array}$ & 0,000096 & 0,000116 & 0,000118 & 0,000115 & 0,000122 & 0,000142 \\
\hline
\end{tabular}

The study found that households consume about $28.8 \%$ of electricity in 2019, with industry, transportation, and other sectors are consuming the rest. So, having energy production [19] and consumer prices [5, 6], as well as consumption patterns by different types of consumers, we can calculate how much electricity is generated in the EU. Let us do this in Table 1.

It is very important to note that the importance of solar energy is growing in the total volume of production. Of course, the figure of $0.0001 \%$ in the total GDP of the EU countries is minuscule. Still, its growing trend shows the importance of solar energy in the energy balance of the European Union countries and the economies.

Despite considerable support for solar energy development through energy market regulation policies, this market's target level of development in the EU could not be achieved without government programs and tools to stimulate investment in renewable energy.
The EU has adopted guidelines for EU countries to develop and reform solar electricity support schemes. This guidance suggests that financial support for renewable energy should be limited to an appropriate level and aimed at building a competitive market. In addition, support schemes should be flexible and responsive to lower production costs and, as technology develops, the level of government support should be gradually reduced. Governments currently offer various tax incentives and related programs to support renewable energy investments [9].

- Financial subsidies, grants, and rebates. Financial grants are one-time payments given to developers or owners of renewable energy projects to offset initial investment costs. The grant program provides a onetime, non-refundable payment to support an energy project or renewable energy development program. Discounts are payments provided to the owner of an 
improved renewable energy facility to offset the previously incurred costs of those improvements. The amount of the rebate, schedule of payments, and eligibility are regulated.

- A production tax credit for electricity production using renewable energy sources. (Production tax credit, PTC) was first legislated in the United States in 1992 [12]. This measure has proven to positively impact the spread and development of renewable energy sources, especially wind power in the United States. PTC has been extended to 12 EU countries.
PTC is a tax credit that is granted for $1 \mathrm{KWt}$ of electricity produced by qualified renewable energy generation facilities (see Table 2). There is no publicly available data on PTC in the European Union.

- Investment tax incentives are available for private investors to reimburse income tax when investing in renewable energy facilities.

- $\quad$ VAT exemption allows homeowners to avoid paying VAT on the purchase of small renewable energy generators.

Table 2. Organization of state incentives for the production of solar energy $6 C-28$ for industry and other consumers, EUR per $1 \mathrm{~m}^{2}$

\begin{tabular}{|c|c|c|c|c|c|c|c|}
\hline \multirow[b]{2}{*}{ Country } & \multirow[b]{2}{*}{$\begin{array}{l}\text { Targets for the } \\
\text { development } \\
\text { of solar energy }\end{array}$} & \multicolumn{4}{|c|}{ Tax benefits } & \multicolumn{2}{|c|}{ Government funding } \\
\hline & & $\begin{array}{l}\text { Financial } \\
\text { subsidies, } \\
\text { grants for } \\
\text { discounts }\end{array}$ & $\begin{array}{c}\text { Investment } \\
\text { and production } \\
\text { tax benefits }\end{array}$ & $\begin{array}{l}\text { Taxation } \\
\text { reduction }\end{array}$ & Benefits & $\begin{array}{l}\text { Government } \\
\text { investments, } \\
\text { loans, grants }\end{array}$ & Bids \\
\hline Austria & + & + & + & & & + & \\
\hline Belgium & + & + & + & + & & & + \\
\hline Bulgaria & + & & & & & + & \\
\hline Croatia & + & & & & & & \\
\hline Cyprus & + & + & & & & & + \\
\hline Czech Republic & + & + & + & + & & + & \\
\hline Denmark & + & + & + & + & & + & + \\
\hline Estonia & + & & & & + & + & \\
\hline Finland & + & + & & + & + & & + \\
\hline France & + & + & + & + & & + & \\
\hline Germany & + & + & + & + & & + & \\
\hline Greece & + & + & + & + & & + & \\
\hline Hungary & + & + & & + & & + & \\
\hline Ireland & + & & & & & & + \\
\hline Italy & + & + & + & + & & + & + \\
\hline Latvia & + & & & + & & & + \\
\hline Lithuania & + & & & & & + & \\
\hline Luxembourg & + & & & & & & \\
\hline Malta & + & & & + & & & \\
\hline Netherlands & + & & + & + & + & + & \\
\hline Poland & + & & & + & & + & + \\
\hline Portugal & + & + & + & + & & + & + \\
\hline Romania & + & & & & & + & \\
\hline Slovakia & + & & & + & & & \\
\hline Slovenia & + & + & + & + & & + & + \\
\hline Spain & + & + & + & & + & & \\
\hline Sweden & + & + & + & + & & + & \\
\hline $\begin{array}{c}\text { United } \\
\text { Kingdom }\end{array}$ & + & + & & + & + & + & \\
\hline
\end{tabular}


- Accelerated depreciation is used by some countries in Europe. Depreciation costs will be recovered from other sources of company profits.

- Microcredit allows households to take out a small loan from a bank to cover the cost of supplying equipment. This model avoids the high upfront costs mainly associated with renewable energy systems since users pay for them in installments over an agreed period.

- Interest-free loans. Some government agencies, such as the Carbon Trust in the U.K., provide interest-free loans to purchase renewable energy-generating equipment.

Loan guarantees. Export agencies or the European Investment Bank can provide funding to eliminate the risks of investing in renewable energy facilities in emerging markets.

Table 2 summarizes the main fiscal and financial instruments used by EU countries to stimulate investment in renewable energy development.

Different groups of investors are active in solar power, which can be classified according to their attitude to risk (technological, facility country readiness), expected profits, length of ownership, and the degree of their involvement.

Large generation companies were the first to invest in solar power plants. Their initial investments tended to extend to projects at the generating company scale, and they often created new projects. In the last three years, however, the main generation companies in Europe have suffered because of the increase of solar power in the energy mix and the resulting downward impact on the market price of electricity.

Much smaller municipal generation companies, mainly located in Germany and Switzerland, are also active investors. Strongly influenced by the political leadership and the consumer community, many municipal generation companies aim to generate $100 \%$ of their energy from renewable sources. Initially, municipal generation companies bought existing facilities but recently have changed their investment strategy to create partnerships with developers, giving them a request for a large number to be developed.

Independent power producers have become prominent investors in renewable energy in the course of their development. In addition, some of the producers who were operating on traditional fossil fuels have switched to renewable energy sources. Such organizations tend to be actively involved in generating facilities but vary significantly in their geographic advantages and attitude toward risk.

OEMs (original equipment manufacturers) have significantly increased their investments in renewable energy projects to intensify their manufacturing strategies and support equipment sales over the past three years.

Infrastructure and private equity funds were among the first investors in renewable energy. Both types of funds tend to have the same funders but use different investment strategies. Infrastructure funds are focused on sustainable returns and thus invest only in stable countries in operating facilities on mature technologies. On the other hand, private investment funds are interested in high returns and therefore invest during the development and construction phases of a project characterized by higher risks.

Pension funds and insurance companies also invest or co-invest directly in this sector. Most of them concentrate on investing in existing facilities, although some invest during the construction phase with an entire contractor.

YieldCos and closed-end investment funds are the latest category of investors to enter the solar market. Their emergence was driven by a high level of demand for more liquid investment instruments in this sector and the continued decline in traditional bond yields. In addition, YieldCos tend to invest in solar and wind power plants, which focus on good returns for investors. YieldCos generate significant returns to shareholders through dividends from electricity sales [27].

Sources of microcredit. The European microfinance sector is still underdeveloped. In addition, most of the participants are very small. Most organizations in the microcredit sector do not provide more than 100 loans per year. Almost $70 \%$ of the microcredit companies use no more than five people in the microfinance program. In general, there is no uniform business model for microfinance in Europe [28].

Regarding the volume of investment, it is carried out following the established renewable energy development programs in the European Union. These are the programs of the European Regional Development Fund (ERDF) and the Cohesion Fund (CF). In particular, until 2013, there was one funding program worth 1,064 million EUR, and from 2014 to 2020, there was another funding program worth 1,804 million EUR (European Court of Auditors, 2020). We should note that more money was spent on solar energy during the second program, which is reflected in Figure 2.

Thus, considering the state investment in solar energy of 1,804 million EUR, the countries received 124 million EUR during the study period. Given that the marginal costs are almost zero, it is easy to calculate the payback period of about 14 years. However, the state's fiscal interest is not the formation of the gross product but the receipt of taxes. That is why let's determine the tax burden on solar power generation.

It should be noted that both households and industry pay VAT as part of payments for electricity. At the same time, we note that the average tax component for households is about $15.5 \%$. Other taxes account for about $41.3 \%$ of the cost of electricity in the EU-28. The tax burden is more significant for the residents of Denmark; they pay $66.4 \%$ of taxes as part of the electricity costs. Residents of the Netherlands have a lower tax burden; they pay only 3.3 percent of taxes as part of the cost of electricity $[5,6]$.

When it comes to industry, the average tax burden is $35 \%$, with German businesses paying the most taxes at around $52.3 \%$ and Swedish companies paying the least at $0.6 \%$, as shown in Figure 3 . 


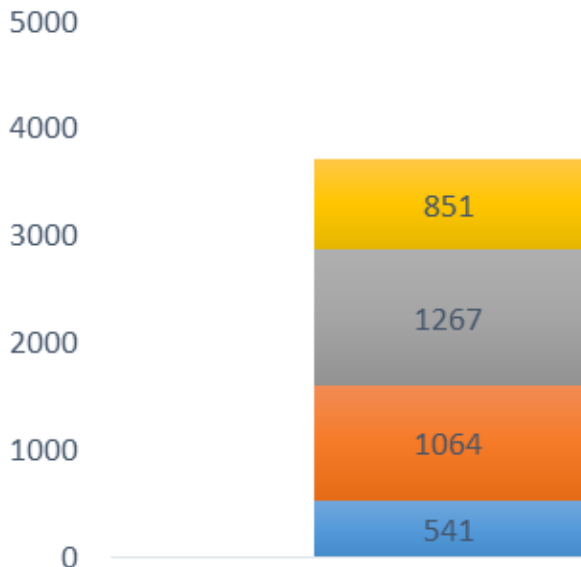

2007-2013

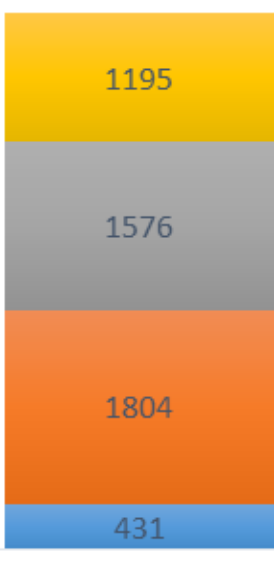

2014-2020

WIND $\square$ SOLAR $\square$ BIOMASS $\square$ OTHER

Figure 2. Structure of state investments in the development of renewable energy in the EU countries during 2007-2020, million EUR [29]

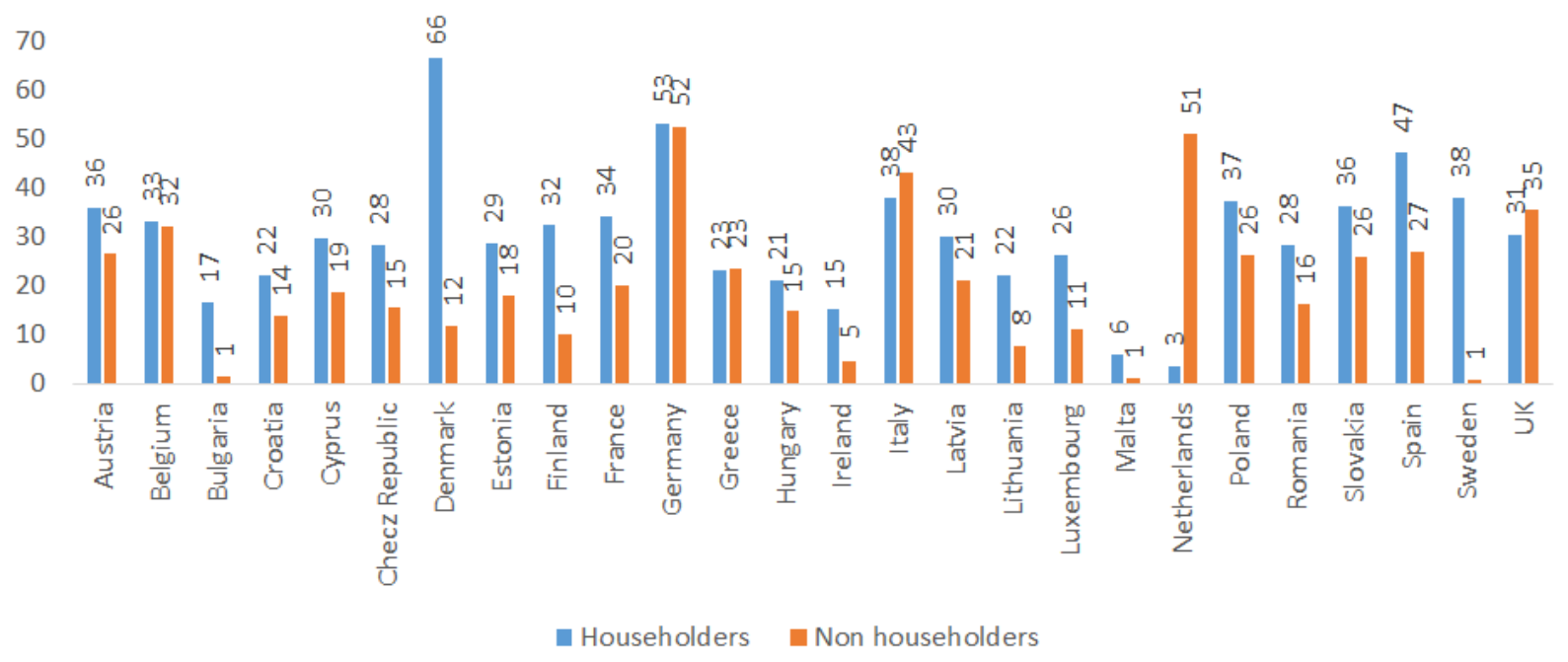

Figure 3. Taxes share in the electricity cost in the EU countries as of 2019, in \% [6].

Let's also show the main figures for solar energy production, the cost of electricity, and taxes collected for electricity used by EU countries for 2019 in Table 3.

Table 3. The amount of generated solar electricity taxation by EU-28 countries in 2019

\begin{tabular}{cccc}
\hline Country & Produced solar electricity, MWt & $\begin{array}{c}\text { Cost of generated solar electricity, } \\
\text { thousand EUR }\end{array}$ & Taxes, thousand EUR \\
\hline Latvia & 3,0 & 0,4 & 0,1 \\
\hline Ireland & 36,0 & 6,0 & 0,5 \\
\hline Malta & 151,0 & 20,1 & 0,5 \\
\hline Lithuania & 83,0 & 8,5 & 1,0 \\
\hline Croatia & 69,0 & 7,7 & 1,3 \\
\hline Estonia & 107,0 & 11,2 & 2,4 \\
\hline Luxembourg & 141,0 & 16,3 & 2,5 \\
\hline Finland & 215,0 & 21,6 & 3,6 \\
\hline Cyprus & 129,0 & 23,1 & 5,0 \\
\hline Slovenia & 222,0 & 25,6 & 5,2 \\
\hline
\end{tabular}


Table 3 Continued

\begin{tabular}{cccc}
\hline Bulgaria & 1065,0 & 97,8 & 5,6 \\
\hline Sweden & 698,0 & 79,7 & 9,1 \\
\hline Slovakia & 472,0 & 64,7 & 21,4 \\
\hline Hungary & 1277,0 & 129,4 & 29,7 \\
\hline Romania & 1386,0 & 150,1 & 40,5 \\
\hline Denmark & 1080,0 & 147,2 & 42,1 \\
\hline Czech Republic & 2100,0 & 220,6 & 42,7 \\
\hline Poland & 1317,0 & 145,0 & 45,0 \\
\hline Portugal & 907,0 & 131,2 & 65,4 \\
\hline Austria & 1661,0 & 224,6 & 79,9 \\
\hline Greece & 2794,0 & 342,0 & 239,8 \\
\hline Belgium & 4530,0 & 741,3 & 317,4 \\
\hline France & 10576,0 & 1312,6 & 325,8 \\
\hline Netherlands & 6924,0 & 876,1 & 457,6 \\
\hline Spain & 9233,0 & 1393,7 & 782,7 \\
\hline United Kingdom & 13616,0 & 2304,7 & 1591,8 \\
\hline Italy & 20864,0 & 3829,3 & 5143,8 \\
\hline Germany & 49016,0 & 9793,0 & 9281,1 \\
\hline Total & 130672 & 22123,3 & \\
\hline
\end{tabular}

Note: the author's calculations

Given the analysis of solar energy production indicators and the level of taxation of electricity used, we have the opportunity to form a hypothesis.

Hypothesis: the development of solar energy and electricity prices contribute to increased budget revenues.

Table 4. Output data for calculating the dependence of tax revenues to the state budget from solar energy produced by EU-28 countries for 20142019

\begin{tabular}{cccc}
\hline & $\mathrm{X}_{1}$ & $\mathrm{X}_{2}$ & $\mathrm{Y}$ \\
\hline $\begin{array}{c}\text { Produced solar } \\
\text { electricity, MWt }\end{array}$ & $\begin{array}{c}\text { Cost of generated } \\
\text { solar electricity, } \\
\text { thousand EUR }\end{array}$ & $\begin{array}{c}\text { Taxes, } \\
\text { thousand } \\
\text { EUR }\end{array}$ \\
\hline 2014 & 87340 & 15004 & 6539 \\
\hline 2015 & 94422 & 15751 & 6856 \\
\hline 2016 & 101078 & 16347 & 7089 \\
\hline 2017 & 106382 & 16944 & 7355 \\
\hline 2018 & 114550 & 19372 & 8012 \\
\hline 2019 & 130672 & 22123 & 9281 \\
\hline
\end{tabular}

In order to confirm this hypothesis, let us conduct a correlation and regression analysis between the indicators of solar energy production by EU countries, the cost of electricity and the amount of taxes received (Table 4).

According to the calculations we get the following statistical indicators:

- $\quad$ Multiple $\mathrm{R}=0,997$;

- $\quad \mathrm{R}^{2}=0,994$

- $\quad$ Adjusted $\mathrm{R}^{2}=0,990$;

- $\quad$ Standard Error 98,424;

- Observations6;

- $\quad$ X Variable $1=0,004$

- $\quad X$ Variable $2=0,35$;

- $\quad$ Intercept $=814,98$.

Thus, the calculations confirm the high degree of intensity of the link between the indicators, which allows us to derive the formula for the linear dependence:

$$
\mathrm{y}=0.004 \mathrm{x}_{1}+0.35 \mathrm{x}_{2}+814.98
$$

Using the dependence formula, we can simulate the change in the end indicator of the amount of taxes on the amount of output of solar energy and the value of the generated energy in Table 5.

Table 5. Output data for calculating the dependence of tax revenues to the state budget from solar energy produced by EU-28 countries for 20142019

\begin{tabular}{cccccc}
\hline 815,0 & 15004,2 & 15925,9 & 16533,8 & 17140,8 & 19361,3 \\
87340,0 & 6495,7 & 6820,5 & 7034,7 & 7248,6 & 8031,2 \\
94421,5 & 6527,5 & 6852,3 & 7066,6 & 7280,5 & 8063,1 \\
101078,3 & 6557,4 & 6882,3 & 7096,5 & 7310,4 & 8093,0 \\
106382,3 & 6581,3 & 6906,1 & 7120,4 & 7334,3 & 9004,6 \\
114550,0 & 6618,0 & 6942,9 & 7157,1 & 7371,0 & 9036,5 \\
130672,0 & 6690,5 & 7015,4 & 7229,6 & 7443,5 & 8153,6 \\
\hline
\end{tabular}




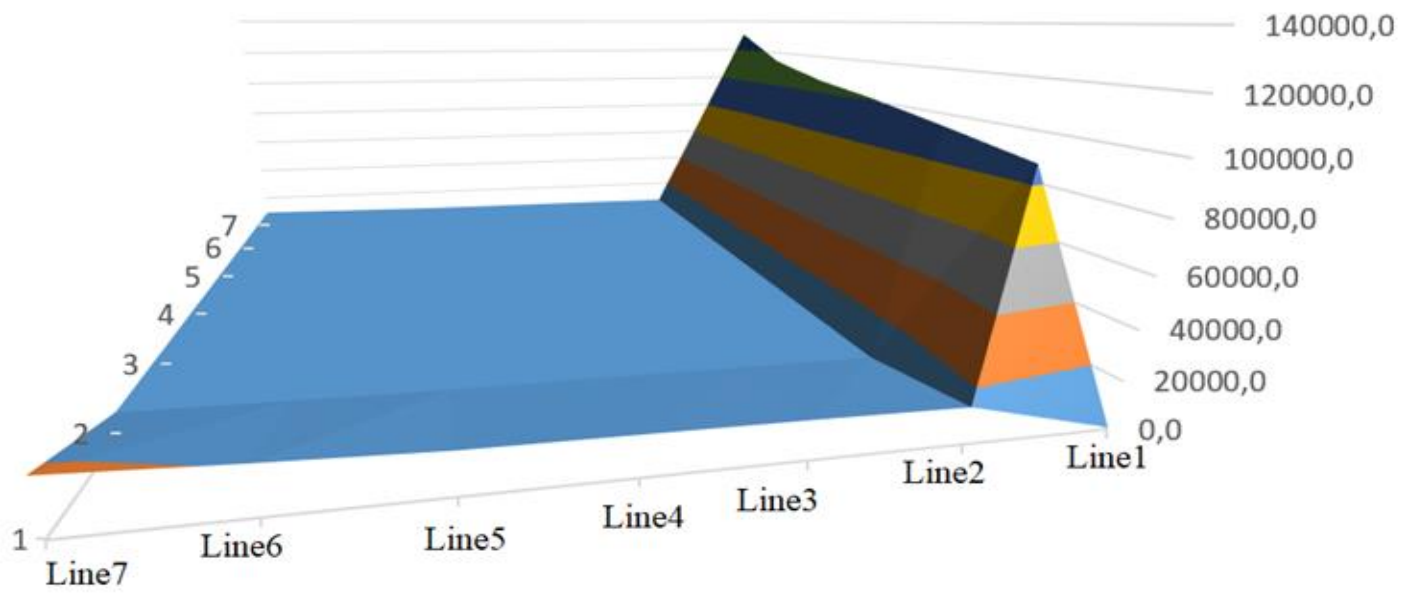

\author{
= $0,0-20000,0=20000,0-40000,0=40000,0-60000,0=60000,0-80000,0$ \\ 물 $80000,0-100000,0=100000,0-120000,0=120000,0-140000,0$
}

Note: the author's calculations

Figure 4. The result of modeling the change in tax revenues of the EU countries depending on the volume of production of solar energy and its cost

This correlation between the indicators is graphically represented as a plane, which shows that the higher the amount of investment (and accordingly the production of solar energy), the more the country receives tax revenues, which is shown in Figure 4.

Thereby, the hypothesis set at the beginning of the research is confirmed, which means that it confirms the value of solar energy not only for the improvement of ecology but also in the energy balance and the economy as a whole. It can be argued that despite the high level of costs for the creation of power plants, the countries that can stimulate their construction in the long term will have a significant effect, which is evaluated not only by energy independence but also as a result of political and economic.

\section{Conclusions}

This article reveals the financial aspects of solar energy in the EU countries by comparing public revenues and expenditures for the creation of solar energy. Practice shows that compared to other energy resources, solar energy is not profitable for the countries' budgets, as the costs of its development significantly exceed the revenues. However, given the strategy adopted by the countries of the European Union to improve the environment by reducing $\mathrm{CO} 2$ emissions, the product of solar energy is one of the effective ways to solve the situation. In recent years, about 50 billion EUR have been invested annually in constructing solar and wind power plants. Investments in the development of solar power plants are paid back by an increase in the amount of energy produced. The average increase in the EU countries is about $14 \%$ per year.

According to research data, it is clear that households in the European Union use more resources - up to $29 \%$.

The analysis of the impact of solar energy on GDP has shown that, at present, the EU states cannot rely on these energy resources as a significant source of domestic product formation. However, the annual growth of the share of solar energy in the total volume of production should be noted.

Today, most governments believe that households are essential in the development of solar energy. However, since investments in solar power are long-term and risky due to the further decrease in the cost of energy resources, households are reluctant to invest in solar power plants. Therefore, states are taking it upon themselves to encourage such investment by developing financial subsidy programs, tax breaks, investment incentives, tax exemptions, accelerated depreciation, microcredit, interestfree loans, loan guarantees, and the like. At the same time, it should be noted that the level of additional income from solar energy is not comparable with the level of investment. In particular, if EUR 1.8 billion were invested in developing a solar power plant between 2014 and 2020, then about EUR 0.53 billion of additional income was received during the same period. If we take into account 2014 prices, the payback period will be about 18 years. Therefore, we can conclude that investment projects in solar energy are not very interesting for private businesses. Still, long-term projects that will result in energy independence are necessary and economically feasible for 
the state.

However, the state is interested in return on investment and indirect budget revenues from the taxation of energy produced. An analysis of the tax systems of EU countries showed that the cost of energy taxes from households by $41 \%$ and businesses by $35 \%$. In 2019, EU countries received about 9 million EUR in tax revenues from consumed solar electricity. Furthermore, a correlation and regression analysis showed that the higher the investment in solar power (and therefore solar electricity generation), the more tax revenue the country would receive. This fact confirms the importance of solar energy in improving the environment and the energy balance, and the economy as a whole.

\section{REFERENCES}

[1] Best, R.; Chareunsy, A.; Li, H. "Equity and effectiveness of Australian small-scale solar schemes", Ecological Economics, 180, 2021, DOI: https://doi.org/10.1016/j.ecolec on. 2020.106890

[2] D'Adamo, I., Gastaldi, M., Morone, P. "The post COVID-19 green recovery in practice: Assessing the profitability of a policy proposal on residential photovoltaic plants", Energy Policy, 147, 2020, DOI: https://doi.org/10.1016/j.enpol.202 0.111910

[3] Dykan, V., Pakharenko, O., Saienko, V., Skomorovskyi, A., \& Neskuba, T. "Evaluating the efficiency of the synergistic effect in the business network", Journal of Eastern European and Central Asian Research, 8(1), pp. 51-61, 2021, DOI: https://doi.org/10.15549/jeecar.v8i1.646

[4] Electricity prices components for household consumers annual data (from 2007 onwards). Eurostat. Available online: https://appsso.eurostat.ec.europa.eu/nui/show.do?dat aset=nrg_pc_204_c\&lang=en

[5] Electricity prices components for non-household consumers - annual data (from 2007 onwards). Eurostat. Available online: https://appsso.eurostat.ec.europa.eu/nui/show.do?dat aset=nrg_pc_205_c\&lang=en (accessed on 11 December 2020).

[6] Electricity Prices. Eurostat, https://ec.europa.eu/eurostat/stat istics- explained/index.php?title=File:Electricity_prices,_firs t_semester_of_2017-2019_(EUR_per_kWh).png (accessed on 11 December 2020).

[7] Energy summary for EU28. EU Energy Statistic. Available online: https://energy.at-site.be/eurostat/EU/EU28/(accessed on 11 December 2020).

[8] European Commission. A European Green Deal, https://ec.europa.eu/info/strategy/priorities-20192024/european-green-deal_en

[9] Global Trends in Renewable Energy Investment 2020. FC UNEP CENTRE, https://www.fs-unep-centre.org/globaltrends-in-renewable-energy-investment-2020/ (accessed on 11 December 2020).
[10] Hernandez, R.R.; Easter, S.B.; Murphy-Mariscal, M.L.; Maestre, F.T.; Tavassoli, M.; Allen, E.B.; Barrows, C.W.; Belnap, J.; Ochoa-Hueso, R.; Ravi, S.; et al. "Environmental impacts of utility-scale solar energy", Renew. Sustain. Energy Rev, 29, pp. 766-779, 2014, DOI:10.1016/j.rser.2013.08.041

[11] Hu, A.; Levis, S.; Meehl, G.A.; Han, W.; Washington, W.M.; Oleson, K.W.; van Ruijven, B.J.; He, M.; Strand, W.G. "Impact of solar panels on global climate", Nature Clim. Chang, 2015. DOI:10.1038/nclimate2843

[12] Implications of a PTC Extension on U.S. Wind Deployment. Energy, https://www.energy.gov/eere/analysis/downloads/i mplications-ptc-extension-us-wind-deployment (accessed on 11 December 2020).

[13] Lazorko, O., Virna, Z., Brytova, H., Tolchieva, H., Shastko, I., \& Saienko, V. "Professional Safety of Personality: System Regularities of Functioning and Synergetic Effects of SelfOrganization", Postmodern Openings, 12(2), pp.170-190, 2021, DOI:https://doi.org/10.18662/po/12.2/30 2

[14] Naci Celik A., Muneer T., Clarke P. “A review of installed solar photovoltaic and thermal collector capacities in relation to solar potential for the EU-15". Renewable Energy, Vol. 34, Issue 3, pp. 849-856, 2009, DOI: https://doi.org/10.1016/j.renene.2008.05.025

[15] Ng, K.S.; To, L.S. "A system thinking approach to stimulating and enhancing resource efficiency and circularity in households", Journal of Cleaner Production, 275, 2020, DOI: DOI:10.1016/j.jclepro.2020.123038

[16] Ocal, O., \& Aslan, A. "Renewable energy consumptioneconomic growth nexus in Turkey". Renewable and Sustainable Energy Reviews, 28, 494-499, 2013.

[17] Perpiña Castillo C., Batista e Silva F., Lavalle C. “An assessment of the regional potential for solar power generation in EU-28". Energy Policy, Vol. 88, pp. 86-99, 2016, DOI: https://doi.org/10.1016/j.enpol.2015.10.004

[18] Petrovich, B., Carattini, S., Wüstenhagen, R. "The price of risk in residential solar investments", Ecological Economics, 180, 2021, DOI: 10.1016/j.ecolecon.2020.1068 56

[19] Photovoltaic Barometer. Eurobserv'er. 2019. Available online: https://www.eurobserv-er.org/photovoltaicbarometer-2020/ (accessed on 11 December 2020)

[20] Pirlogea, S., \& Cicea, S. "Econometric perspective of the energy consumption and economic growth relation in European Union". Renewable Sustainable Energy Review, 16, 5718-5726, 2012. DOI: https://doi.org/10.1016/j.rser.20 13.08.036

[21] Radov, D. "Update on Energy Taxation and Subsidies in Europe: An Analysis of Government Revenues from and Support Measures for Fossil Fuels and Renewables in the EU and Norway". IOGP, http://www.iogp.org/bookstore/wp -content/uploads/sites/2/2018/06/NERA-Energy-Revenueand-Expenditure-May-2018.pdf (accessed on 11 December 2020).

[22] Renewable energy investment Europe. Statista, https://www.statista.com/statistics/1066269/renewableenergy-investment-europe/ (accessed on 11 December 2020). 
[23] Sahlian, D.N.; Popa,A.F.; Cre tu, R.F. "Does the Increase in Renewable Energy Influence GDP Growth?" An EU-28 Analysis. Energies, 14, 2021. DOI: https://doi.org/10.3390/e n14164762

[24] Sanz-Casado E., Lascurain-Sáncheza M., Eleazar SerranoLopeza A., Larsen B., Ingwersen P. "Production, consumption and research on solar energy: The Spanish and German case",Renewable Energy, Vol. 68, pp. 733-744, 2014, DOI: https://doi.org/10.1016/j.renene.2014.03.013

[25] Sebri, M., \& Ben-Salha, O. "On the causal dynamics between economic growth, renewable energy consumption, $\mathrm{CO} 2$ emissions and trade openness: Fresh evidence from BRICS countries". Renewable and Sustainable Energy Reviews, 39, 14-23, 2014. DOI: https://doi.org/10.1016/j.rse r.2014.07.033

[26] Solar Energy Market. Allied Market Research. Available at: https://www.alliedmarketresearch.com/solar-energy-market

[27] The European renewable energy investor landscape (2017) SILO TIPS, https://silo.tips/download/the-europeanrenewable-energy-investor-landscape (accessed on 11
December 2020).

[28] Use of Microfinance Institutions (MFI) for Renewable Energy Technologies. Energypedia, https://energypedia.info /wiki/Use_of_Microfinance_Institutions_(MFI)_for_Renew able_Energy_Technologies (accessed on 11 December 2020).

[29] Wind and solar power for electricity generation: significant action needed if EU targets to be met. European Court of Auditors, https://op.europa.eu/webpub/eca/specialreports/wind-solar-power-generation-8-2019/en/ (accessed on 11 December 2020).

[30] Zhang, M.M.; Zhang, C.; Liu, L.Y.; Zhou, D.Q. "Is it time to launch grid parity in the Chinese solar photovoltaic industry? Evidence from 335 cities", Energy Policy, 147, 2020, DOI: https://doi.org/10.1016/j.enpol.2020.111733

[31]Zhe, L., Yuksel, S., Dincer, H., Mukhtarov, S., Azizov, M. "The Positive Influences of Renewable Energy Consumption on Financial Development and Economic Growth”. Sage Open, 2021. DOI: https://doi.org/10.1177/21 582440211040133 